Article

\title{
Functional and Operational Requirements to Be Fulfilled by Conical Picks Regarding Their Wear Rate and Investment Costs
}

\author{
Krzysztof Krauze ${ }^{1}$, Kamil Mucha ${ }^{1, *} \mathbb{( D}$, Tomasz Wydro ${ }^{1}$ and Edward Pieczora ${ }^{2}$ \\ 1 Faculty of Mechanical Engineering and Robotics, AGH University of Science and Technology, \\ Mickiewicza 30 Street, 30-059 Kraków, Poland; krauze@agh.edu.pl (K.K.); wydro@agh.edu.pl (T.W.) \\ 2 KOMAG Institute of Mining Technology, Pszczyńska 37 Street, 44-100 Gliwice, Poland; epieczora@komag.eu \\ * Correspondence: kmucha@agh.edu.pl
}

Citation: Krauze, K.; Mucha, K.; Wydro, T.; Pieczora, E. Functional and Operational Requirements to Be Fulfilled by Conical Picks Regarding Their Wear Rate and Investment Costs. Energies 2021, 14, 3696. https://doi.org/10.3390/en14123696

Academic Editors: Sergey Zhironkin and Maxim Tyulenev

Received: 4 May 2021

Accepted: 15 June 2021

Published: 21 June 2021

Publisher's Note: MDPI stays neutral with regard to jurisdictional claims in published maps and institutional affiliations.

Copyright: (c) 2021 by the authors. Licensee MDPI, Basel, Switzerland. This article is an open access article distributed under the terms and conditions of the Creative Commons Attribution (CC BY) license (https:/ / creativecommons.org/licenses/by/ $4.0 /)$.

\begin{abstract}
User's choices of conical picks currently involve specifying their material and geometric parameters (functional requirements), incorporating the place and conditions of their work (operational requirements). The selection is usually made based on solely one criterion, which is the price. Thus, at the stage of both purchase and operation, the quality of picks, as well as their matching for a specific machine, are not assessed. The problem of defining whether the producer has fulfilled the user's requirements arises only when the user questions the picks' quality. Analysis of this problem has resulted in developing assumptions, concepts and research procedures based on the cutting process requirements. The procedure allows conducting tests to determine the geometric parameters of a pick, the type of material of the pick body and WC-Co insert, as well as the pick wear rate (intensity). The $C 2$ index describes the wear rate (intensity) - the smaller its value, the slower the pick's wear. Laboratory tests were carried out at the AGH University of Science and Technology in Kraków, Poland. Following the developed method and procedure, the quality of picks was precisely and unambiguously assessed. The $C 2$ index, apart from testing the quality of picks, was also used to forecast their wear. Based on the $C 2$ index, a method is proposed to estimate the wear rate of conical picks provided by different manufacturers and determine the acceptable unit price and operating costs. Thus, it is possible and reasonable to precisely define the investment requirements and appropriately select the pick. Relevant tests were carried out for eight different types of conical picks used in roadheaders, longwall shearers and shaft-boring roadheaders.
\end{abstract}

Keywords: underground mining; longwall shearers; roadheaders; conical picks; quality; costs

\section{Introduction}

Mining minerals consists of separating their parts from the whole using well-known mining methods, appropriate technology and machines. These methods can be divided into mechanical methods and blasting [1-3]. Milling, ploughing or drilling are widely used to extract minerals in underground mines [4-10], whereas digging and picking are open-pit technologies [11]. It is strictly borehole technologies that rely only on drilling, but in multi-step bits, conical picks are also used [6,12].

Machines and devices realising these processes are dedicated to each method and technology of exploitation (underground, open-pit, borehole). In underground mining, these are longwall shearers [3,10,13], roadheaders [2,5-7,14] and shaft shearers [15] or ploughs $[9,10]$, whereas in road construction and open-pit mining, these are road milling machines, excavators and rippers [11]. The machines are equipped with cutting elements or units called cutting heads. The largest group of cutting heads are the milling heads (Figure 1) equipped with cutting picks, i.e., radial, tangent and conical picks (Figure 2). The latter are mainly applied in the mining of natural and artificial minerals [16-19]. They are widely used not only in underground or open-pit mining, but also in the construction industry. 


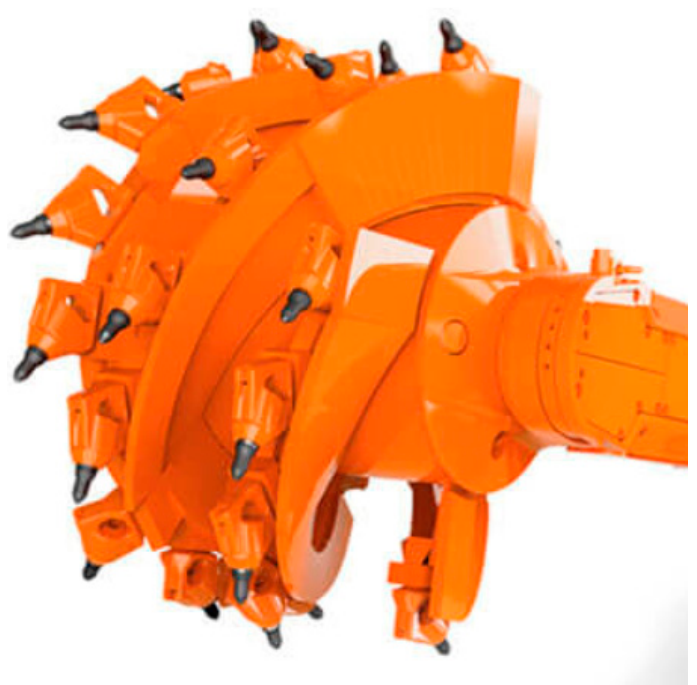

(a)

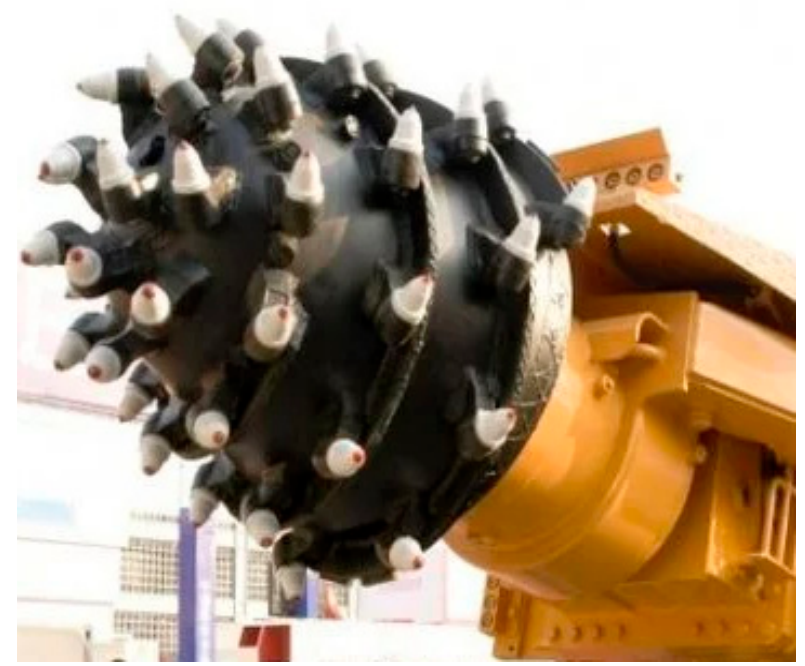

(b)

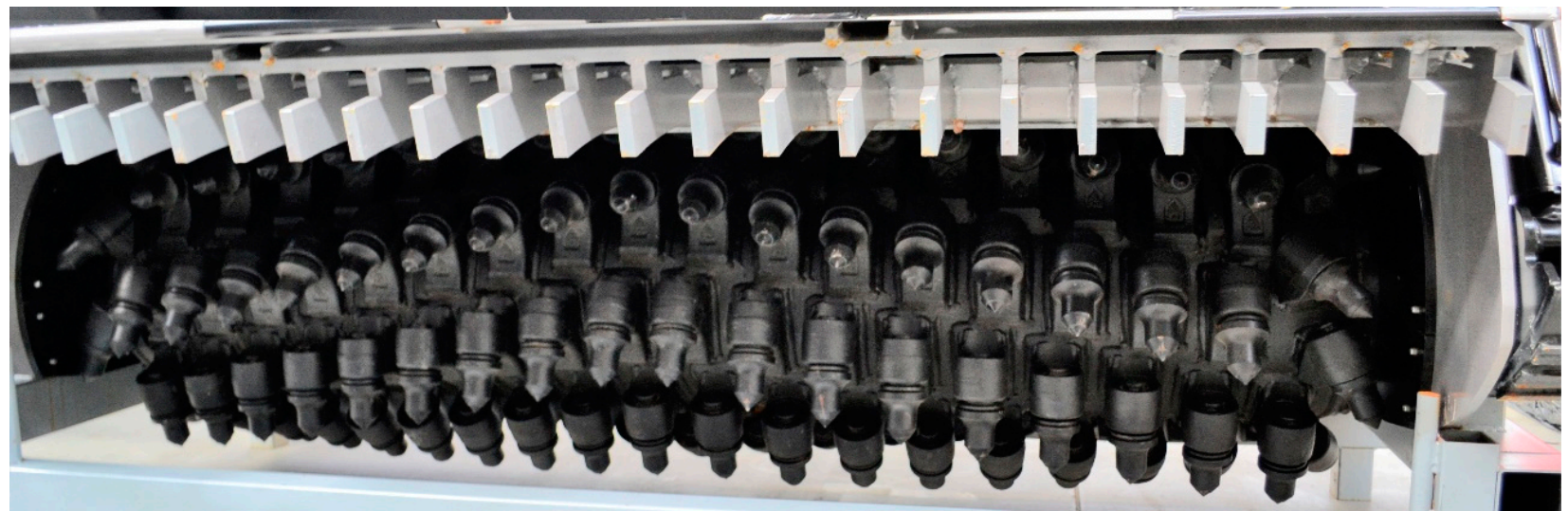

(c)

Figure 1. Cutting heads of: (a) a longwall shearer; (b) a roadheader; and (c) a road milling machine $[13,14,20]$.

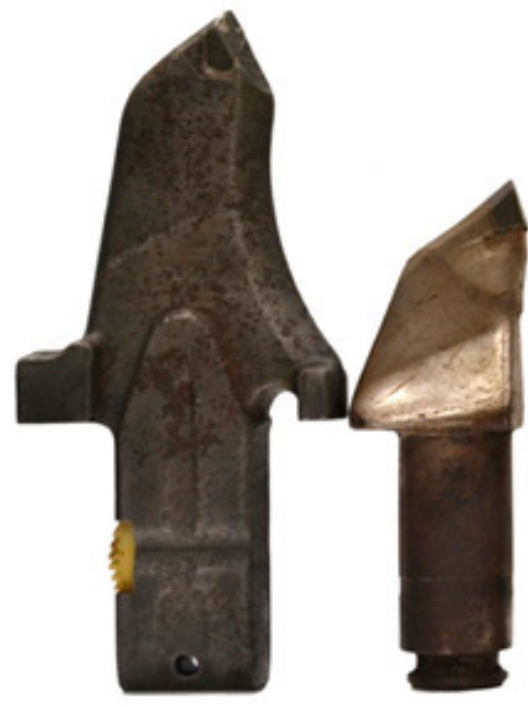

(a)

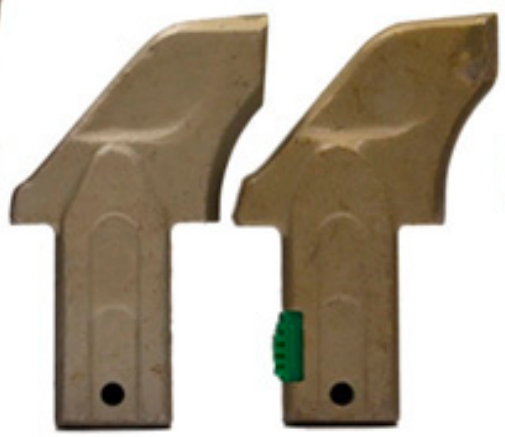

(b)

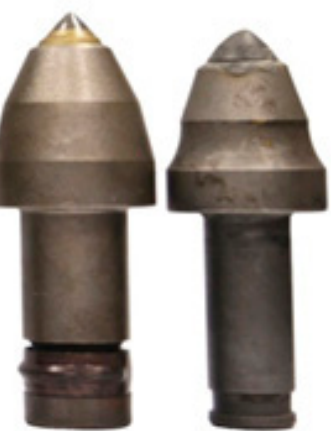

(c)

Figure 2. Cutting picks: (a) tangent; (b) radial; (c) conical. 
Conical picks are used in cutting heads due to their excellent durability, greater than radial or tangent picks. They have a specific structure, where the pick body is a solid of revolution, consisting of working and handle parts [21-23]. The working part is equipped with a WC-Co insert, which is a pick tip [24-27]. On the other hand, the pick holder's gripping part is equipped with a spring-ring, a spring sleeve or a Hert ring [23]. This prevents the pick from falling out of the holder during cutting.

The picks are installed in pick holders, furnished on the cutting head's lateral surface, and together form a system of picks. The rotary mounting of the picks in the holders enables their stochastic rotation and symmetrical wear $[17,18,21]$ (Figure $3 a, c)$. This process occurs if certain conditions related to the cutting angles are obtained [3,28-32]. Otherwise, the picks are blocked in the holders, and their wear is asymmetrical (Figure 3b). There is also the risk of the tip falling out (Figure 3d). This is why the selecting process of the design parameters of the picks and holders is so crucial, considering the geometrical and kinematic parameters of the cutterhead and the cutting machine [2,3,28]. Concurrently, mining and geological conditions must be considered, particularly the mineral's properties when being extracted (cutting resistance, abrasivity) [33-37]. Hence, the user should apply conical picks of the quality required for the premised cutting efficiency and costs [29].

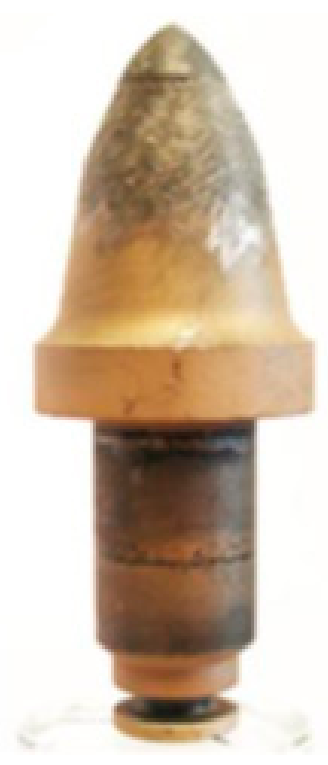

(a)

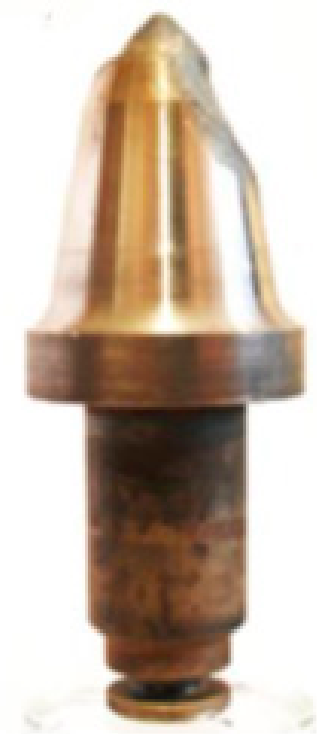

(b)

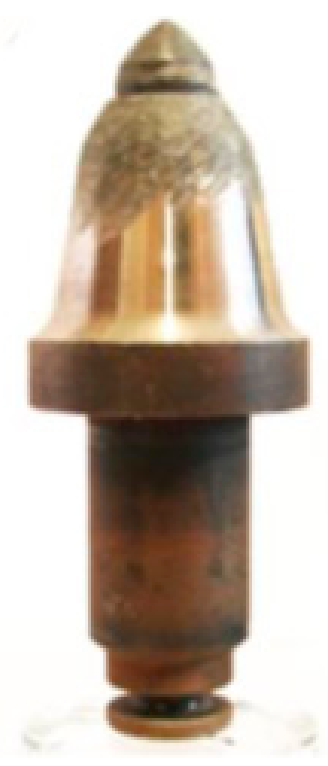

(c)

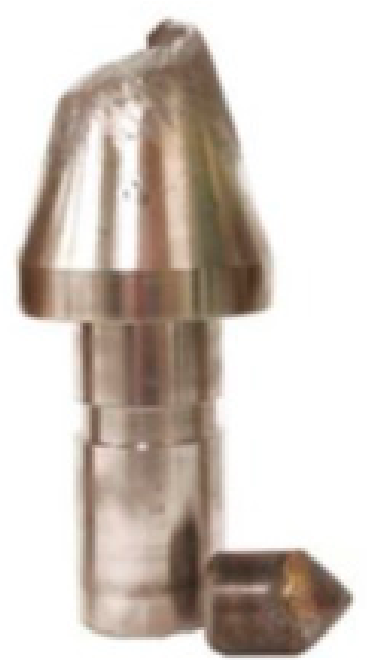

(d)

Figure 3. Worn conical picks: (a) properly (symmetrical); (b) improperly (asymmetrical); (c) with the tip exposed; and (d) with the tip falling out [37].

The required quality of conical picks is related to their appropriate construction (cutting angles, dimensions), material parameters of the pick body (chemical composition, hardness, microstructure, steel grade), and the pick tip (dimensions, HV30 hardness, density, chemical composition-determination of the mass fraction of carbide phase (\%WC), matrix (\%Co) and WC grain size).

A better quality of pick increases the price. This translates into costs involved in purchasing picks and the costs associated with their replacements (operational costs) [29]. Therefore, the quality of picks should be relevant to the required design, material parameters and the rate of their wear. This becomes very important when a user is buying picks from various manufacturers and at different prices. Therefore, the user firstly should pinpoint their requirements and expectations concerning the design and material parameters of the picks. Secondly, a control method should be defined. Then, a decision, as to which picks meet the user's requirements and expectations, is required, with a price adequate to its quality and the assumed cutting efficiency. Hence, a method of determining the quality of conical picks and a procedure for their selection should be applied [28,29]. 
Based on this methodology and the procedures contained therein, different manufacturers' conical picks are tested to compare and assess the picks themselves. This is especially advisable when placing new conical pick designs or material solutions on the market.

For some time now, pick manufacturers have been using various forms of protection of the working part of the pick's surface [22,33,36] (Figure 4). This is often performed by hardfacing with various materials. Their hardness is higher than the native material used to make the body of the pick. In consequence, the abrasion resistance of the working part is better. However, this study revealed that the durability of picks with protected surfaces was not significantly increased compared to standard picks [37]. Hence, based on the research conducted thus far, it has been concluded that investigations need to be continued to find the most effective and cheapest protection and the technology for its implementation.

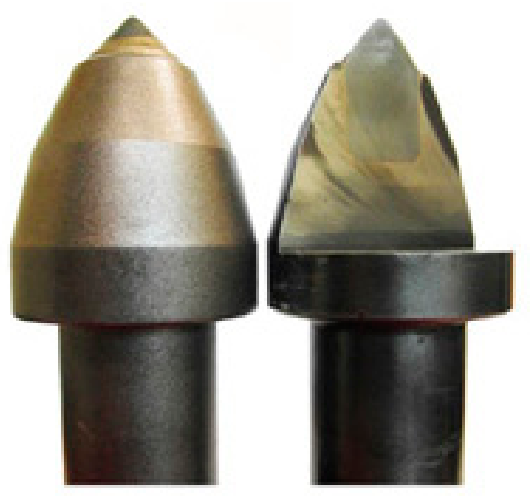

(a)

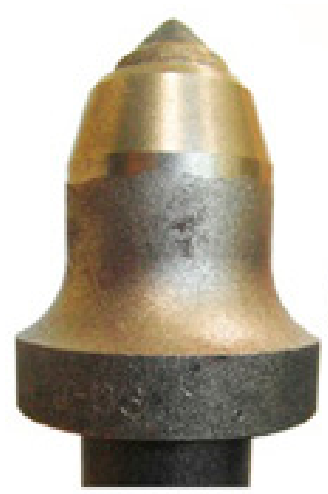

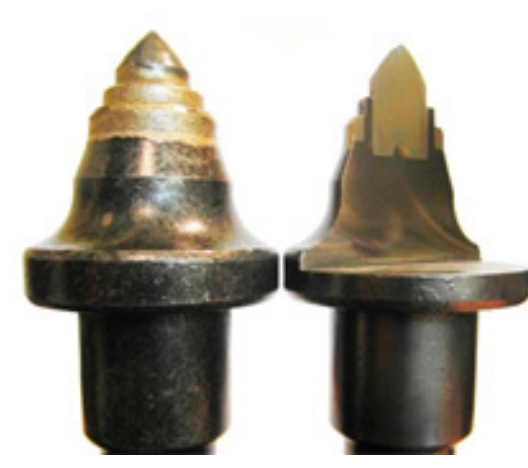

(c)

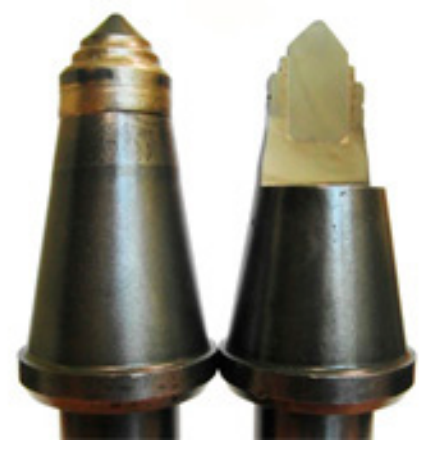

(d) (b)

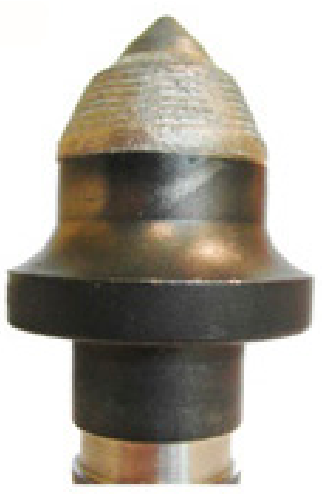

Figure 4. Options of additional protection of conical picks against abrasive wear: (a) standard pick; (b) welded picks; (c) pick with a ring made of WC-Co; (d) pick with two rings made of WC-Co; (e) pick with a lowered body and WC-Co insert in the CAP type [28].

For this purpose, the researchers obtained eight different types of conical picks used on the cutterheads of roadheaders, longwall shearers and shaft-boring roadheaders. These picks were tested according to the methodology described below, and the procedures contained therein (a measurement of constructional and material parameters, wear rate) to assess their quality and wear rate (durability).

\section{Test Procedure for Conical Picks}

The problem mentioned above related to assessing the quality of conical picks has been solved by developing a method and an appropriate procedure for experimentation [28, $29,36,37]$. For the contemporary work of conical picks, the following elements have been considered: 
- The measurement of geometric parameters of the whole pick;

- The measurement of geometric parameters and determining the shape of the pick tip in the form of a WC-Co insert;

- Testing of pick body material parameters;

- Testing of pick tip material parameters;

- Determination of the pick wear rate in laboratory conditions.

Therefore, the tests were carried out in three steps. The first step included measuring the geometric parameters; the second step was material testing; and the third step was measuring the wear rate of conical picks at a laboratory test stand.

The measuring of geometric parameters was conducted first for the whole pick. Next, the pick tip, in the form of a WC-Co insert fixed in the pick body by hard soldering, was obtained in the machining process. Then, it was possible to test the geometric parameters of the WC-Co insert.

The most essential linear and angular dimensions of a conical pick are (Figure 5):

- The length of the working part, $\mathrm{L}_{\mathrm{n}}$;

- The total length, $\mathrm{L}_{\mathrm{c}}$;

- The diameter or diameters of the holder part, $\mathrm{du}, \mathrm{d}_{\mathrm{u} 1}$;

- The diameter of thrust ring flange, $\mathrm{d}_{\mathrm{k}}$;

- The angle of the pick tip, $2 \beta_{\mathrm{u}}$;

- The height of the pick tip, $\mathrm{h}_{\mathrm{w}}$;

- The diameter of the pick tip, $\mathrm{d}_{\mathrm{w}}$.
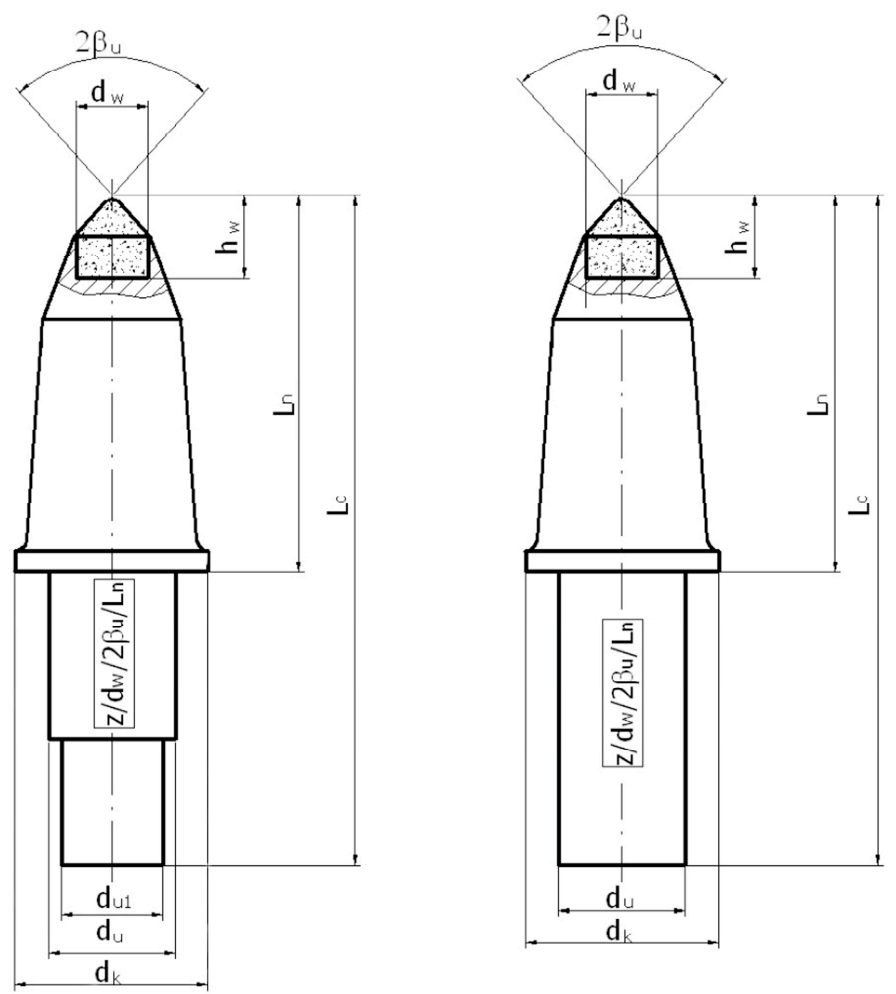

Figure 5. Two- and single-stage conical pick with its measured design parameters [28,29].

The linear dimensions were measured using an altimeter (maximum permissible error $\pm 40 \mu \mathrm{m}$ ) and a calliper (maximum error $\pm 30 \mu \mathrm{m}$ ), while the angles were measured with a protractor characterised by a maximum permissible error of $\pm 2^{\circ}$ ). Figure 6 presents picks on this particular measuring base, equipped with an altimeter, calliper and protractor. 


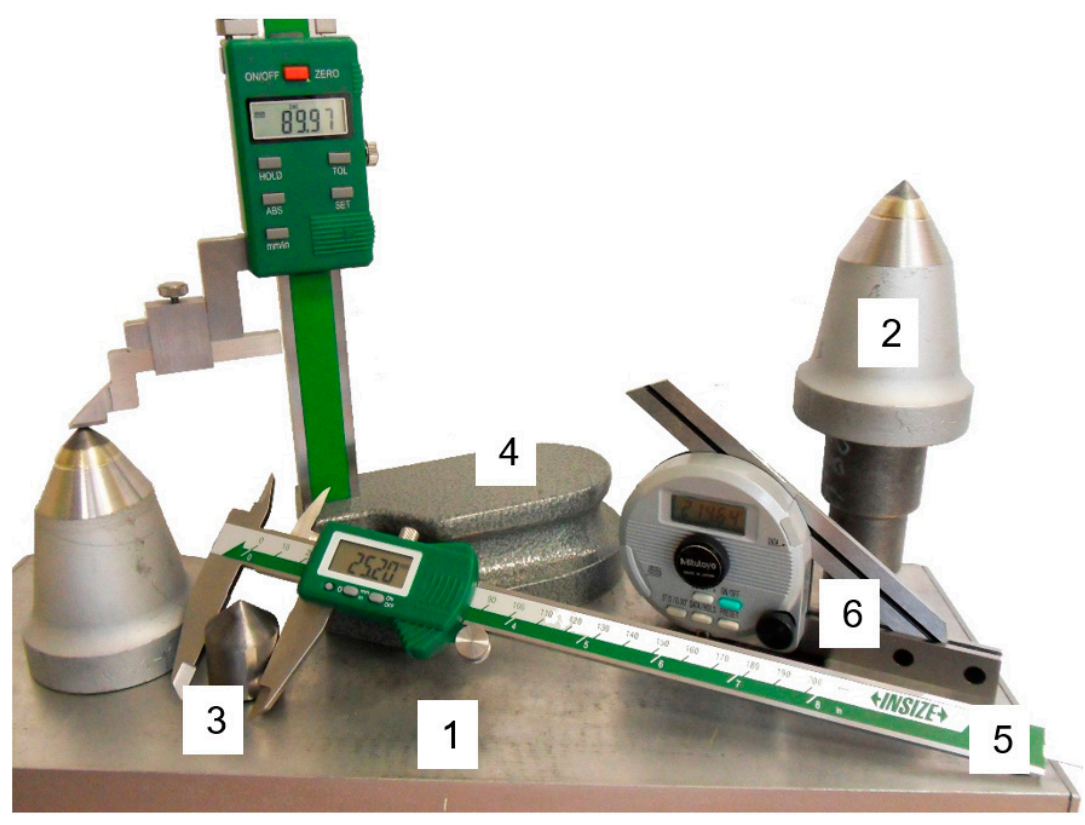

Figure 6. Instruments for measuring linear and angular dimensions: (1) surface plate; (2) conical pick; (3) WC-Co insert; (4) altimeter; (5) calliper; and (6) protractor [28,29].

The next part of the research procedure was material testing, which requires separating the tip from the steel body. Consequently, separate tests should be carried out for two different materials (Figure 7).

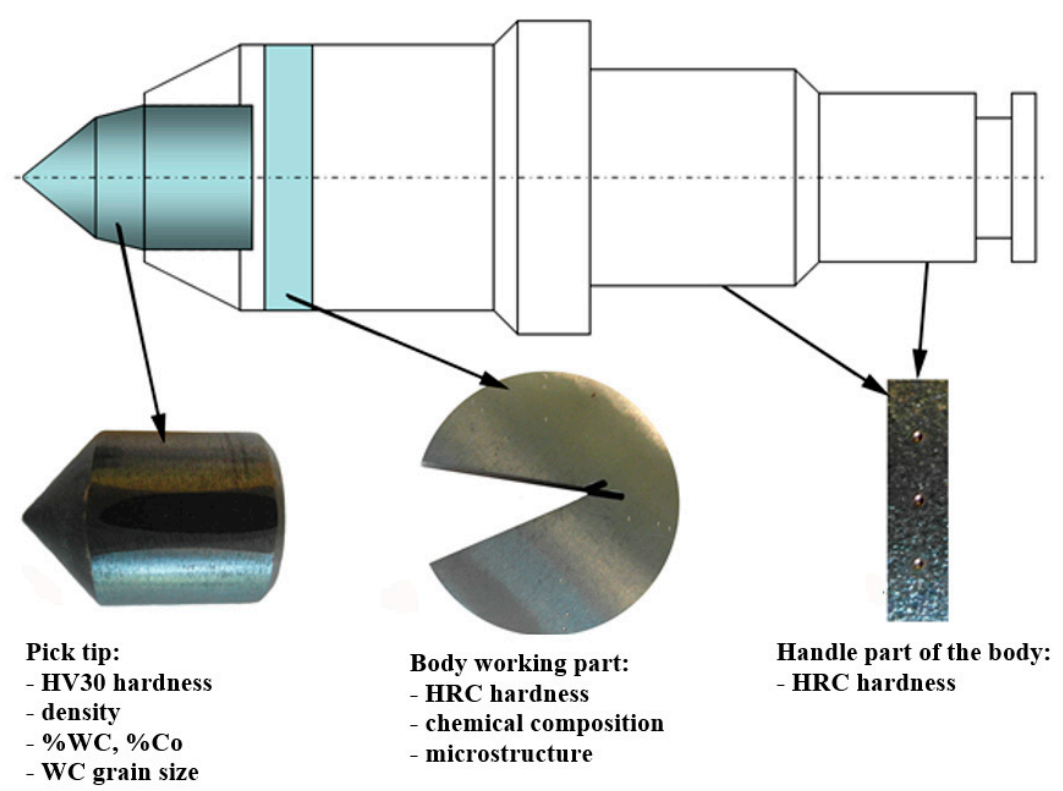

(a)

(b)

(c)

Figure 7. Conical pick with measurement points marked: (a) measurement of tip parameters; (b) measurement of working part parameters; and (c) measurement of gripping part parameters [28,29].

The chemical composition of the pick body material was analysed by the spark method using a Foundry Master device (Figure 8a), whereas the hardness measurement was carried out using the Rockwell method (Figure 8b), following the standard [38], on samples taken from the working part and the gripping part. 


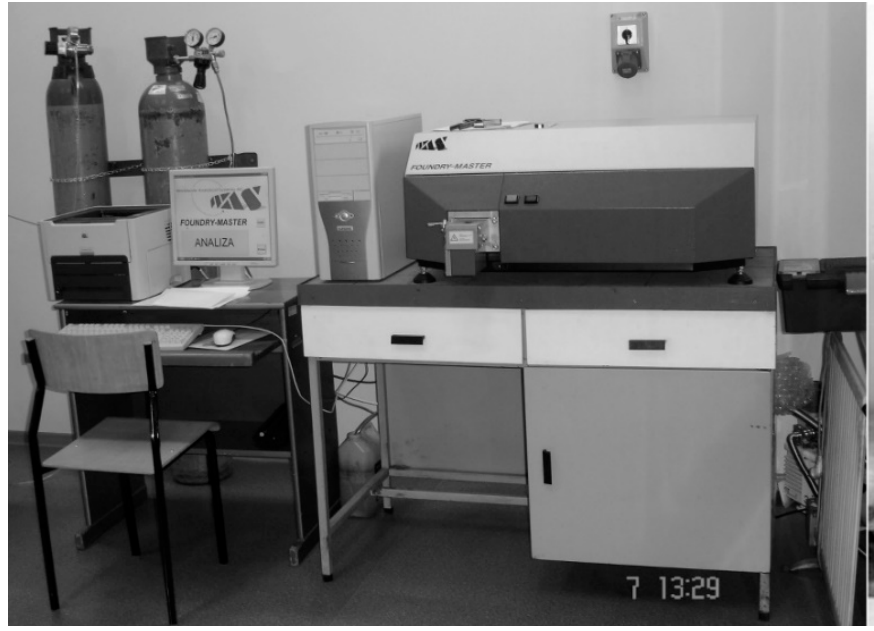

(a)

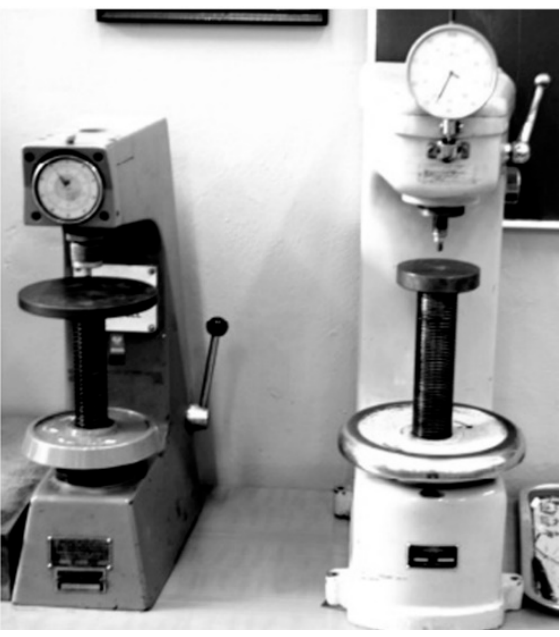

(b)

Figure 8. Instruments for metallographic measurements: (a) Foundry Master device; (b) hardness testers produced by Vickers and Rockwell [29].

WC-Co inserts (pick tips) have a particular chemical composition and mechanical properties primary for the cutting process [24-27]. However, measuring all the parameters of the WC-Co insert leads to a significant increase in research costs while being relatively insignificant for the valuation of the insert suitability for mining a specific rock. Therefore, considering the costs of the test and their subsequent application, it is recommended to perform a quantitative analysis of density and hardness for a mentioned WC-Co insert.

Quantitative analysis of the chemical composition of the WC-Co insert was performed by the X-ray method, using a Mini Pal4 EDXRF Analyser (Energy Dispersive X-ray Fluorescence), produced by Malvern Panalytical (Malvern, UK). The specific density was determined by the hydrostatic weighing method [39], and hardness by the Vickers method [40], using an HPO-250 hardness tester (Figure 8b).

Quantitative description of the WC-Co insert microstructure in the cobalt matrix was performed using the Met-Ilo automated image analysis computer software [41]. The microstructure images for analysis were captured with a DM 4000 light microscope, produced by Leica (Wetzlar, Germany), at 200- and 500-times magnification.

Measurement of the wear rate of conical picks leads to determining their durability. It must always be conducted under the same conditions so that the results are reliable, reproducible and comparable. This enables assessment of the pick durability, but it also allows comparing picks from different manufacturers.

To evaluate the conical picks' durability, their wear rate index was adopted for tests, as described by the $C 2$ index, which is defined as the total loss of mass of the pick or picks concerning the volume of the mined rock obtained (Equation (1)).

$$
C 2=\frac{\Delta m}{m} \cdot \frac{V_{w}}{V_{u n}}[-]
$$

where $C 2$ is the pick wear rate index based on mass, $\Delta m$ is the loss of pick mass during tests (body with the tip) [g], $m$ is the pick mass before tests $[\mathrm{g}], V_{w}$ is the sample standard volume $\left[\mathrm{m}^{3}\right]$, and $V_{u n}$ is the volume of sample mined during tests $\left[\mathrm{m}^{3}\right]$.

The definitions of the above parameters and the requirements for testing the wear rate of conical picks necessitate the use of the following test methodology:

- Cutting an artificial cement-sand sample with almost-isotropic properties;

- Mining by cutting in laboratory conditions;

- Measurement pick's mass before and after the cutting process;

- Measurement of the volume of rock cut. 
Laboratory tests need to be conducted in a unique test stand that meets the adopted test methodology requirements. Therefore, the tests were carried out at a unique laboratory test stand for testing the cutting process with single cutting tools or heads belonging to the AGH University of Science and Technology, Kraków, Poland (Figure 9).

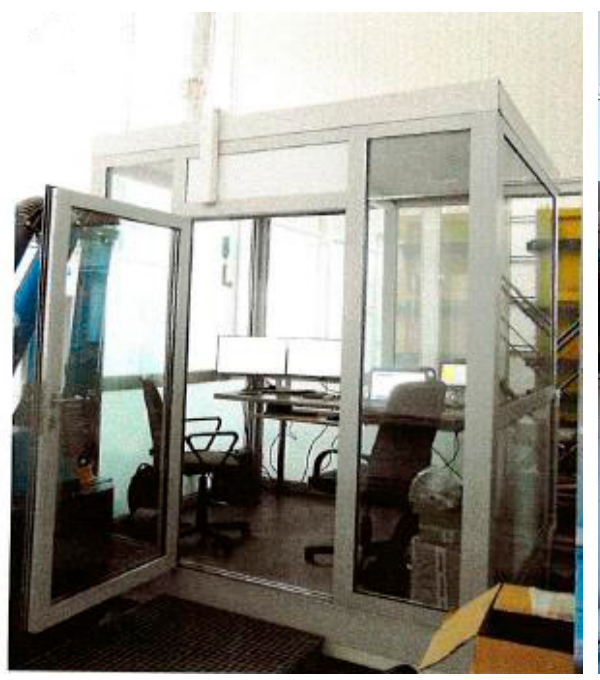

(a)

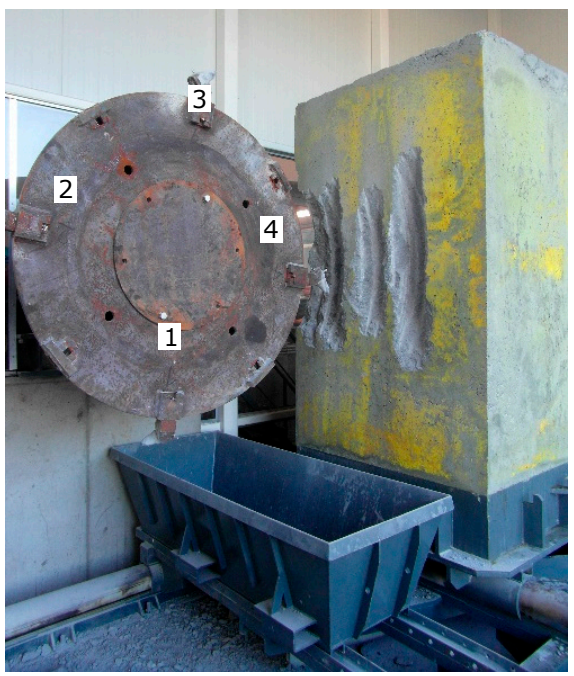

(b)

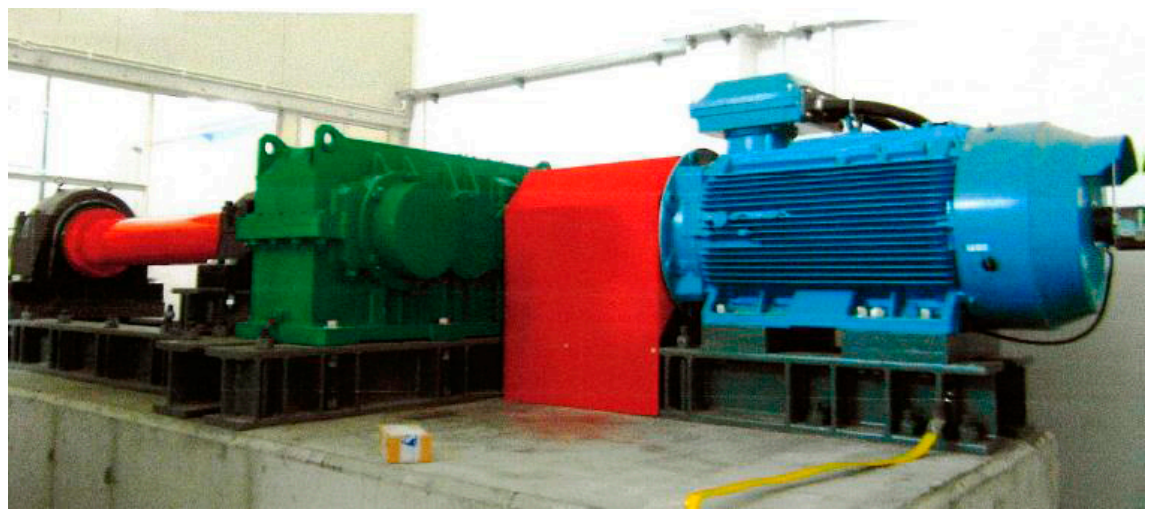

(c)

Figure 9. Laboratory test stand for testing by cutting or rotary drilling with single cutting tools or heads: (a) operator's cab; (b) concrete sample as well as a test cutting head; (c) head drive [29,37].

The test stand consists of two units: a cutting head drive and a block advance system intended for mining. The working element is a unique drum with commercial holders of single-stage and two-stage conical picks.

The rotations of the head and the rectilinear, reciprocating motion of the rock sample in the horizontal plane, allowed the cutting process within a particular area. The hydraulic advance mechanism enabled the base to be moved together with the rock block. The engine revolutions were regulated by the control system located in the control cabinet, while a hydraulic power unit regulated the value of advance rate mining and sumping.

A sample could be placed on the advance mechanism base. In the case of testing the wear rate of conical picks, it is advisable to cut artificial rock (cement-sand sample), which has strong abrasive properties. The test stand was equipped with a measuring system: comprising a torque meter, pressure transducers, distance transducers, and measuring computer. These measured the load of the cutting element, the speed and pressure in the advance system, and, consequently, determined the resistance or energy consumption of the cutting process. 
Four picks mounted in holders of the testing drum were used (Figure 10) to calculate their wear rate. Before testing, each pick had to be marked to enable accurate identification after the tests (position on the test drum).

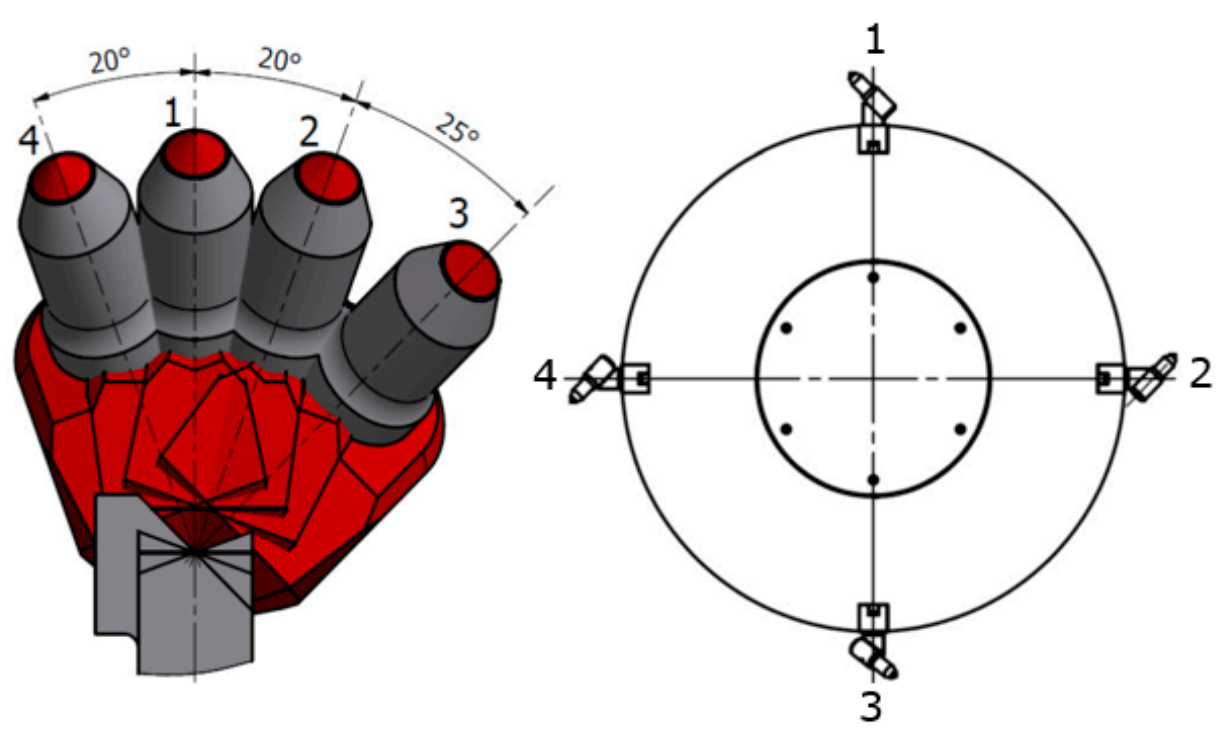

Figure 10. Diagram of the applied pick system with the marking of picks' numbers $[21,28,29,37]$.

Picks were weighed both before and after tests with a certificated laboratory scale (verification scale interval $1 \mathrm{~g}$ ). The obtained weight loss and the excavated rock sample volume were used to calculate the $C 2$ index. It should be emphasised that the smaller the value of the $C 2$ index, the smaller the pick wear. In this case, laboratory tests are particularly recommended, but most importantly, they need to be carried out at a unique test stand that meets the adopted test methodology requirements.

\section{Price of the Conical Pick and Its Wear Rate versus Cutting Efficiency}

The previously described method and its implementation allow for checking the geometric and material parameters of the conical pick body and the tip, as well as the wear rate index, $C 2$.

Therefore, it is reasonable to establish the correlation of the $C 2$ index with the number of worn picks and the cutting efficiency. The dependency (1) shows that the higher the $\mathrm{C} 2$ index value, the faster the pick wears out; thus, it has a lower quality. Using these picks on the cutting drum results in faster wear and a decrease in cutting efficiency. This is caused by a more frequent change of picks and downtime of the mining machine (milling machine). In [29], dependency (2) was given, which indicated when slower wearing and more expensive picks could be used without increasing the purchase costs of picks (3). This condition makes it possible to set the maximum price of a better-quality pick, which results in savings in terms of investment and operation (the cost of purchasing picks, transport, and replacement).

Assuming that the price of a lower-quality pick $C_{n 2}$ is equal to PLN 80 (approx. EUR 20) per piece and the $C 2_{2}: C 2_{1}$ ratio is equal to 1.5 , the price for a better-quality pick $C_{n 1}\left(C 2_{1}\right)$ cannot exceed PLN 120 (approx. EUR 30). However, the $C 2_{2}: C 2_{1}$ ratio may assume different values depending on the $C 2$ index values for individual picks obtained through empirical tests. The ratio is always higher than one when $C 2_{2}$ is higher than $C 2_{1}$.

$$
\begin{gathered}
C 2_{1}<C 2_{2} ; \frac{C 2_{1}}{C 2_{2}}<1 \\
C_{n 1}\left(C 2_{1}\right)<C_{n 2}\left(C 2_{2}\right) \cdot \frac{C 2_{2}}{C 2_{1}}
\end{gathered}
$$


Similarly, from Equations (4) and (5), it is possible to determine the maximum price of a better-quality pick concerning the possible decrease in the cutting efficiency for lowerquality and cheaper picks.

$$
C_{n 1}\left(C 2_{1}\right) \geq \frac{\Delta V_{u} \cdot C_{j u r}}{n}+C_{n 2}\left(C 2_{2}\right) \cdot \frac{C 2_{2}}{C 2_{1}}
$$

or

$$
C_{n 1}\left(C 2_{1}\right) \geq \frac{\gamma_{w} \cdot \Delta V_{u} \cdot C_{j u m}}{n}+C_{n 2}\left(C 2_{2}\right) \cdot \frac{C 2_{2}}{C 2_{1}}
$$

where $\Delta V_{u}$ is the volume of mined rock $\left[\mathrm{m}^{3}\right], \gamma_{w}$ is the density of mined rock $\left[\mathrm{kg} / \mathrm{m}^{3}\right], C_{j u \mathrm{r}}$ is the unit price of mined rock in relation to its volume $\left[\mathrm{PLN} / \mathrm{m}^{3}\right], C_{j u m}$ is the unit price of mined rock in relation to its mass [PLN/ $\mathrm{kg}$ ], and $n$ is the number of picks to be replaced after one cutting cycle [pcs].

Bearing in mind the above dependencies, in most cases, better-quality picks should be used [29].

\section{Research Material}

Five pieces of each type of conical pick were assigned for testing. One pick was intended for material tests, and the other four were for measuring the design parameters and the wear rate. The pick's bodies were made of various grades of steel and reinforced with various cemented carbide (WC-Co) inserts. The surface of the working part of the pick body was protected with various padding welds—reinforced picks (Figure 11b-f)—or was not protected-standard picks (Figure 11a,c,g,h). The following picks were used for testing:

1. Commercial picks for roadheaders-five pcs (Figure 11a);

2. Hardfaced picks for roadheaders-five pcs (Figure 11b);

3. Commercial picks for roadheaders-five pcs (Figure 11c);

4. Commercial picks for shaft-boring roadheaders-five pcs (Figure 11d);

5. Commercial picks for shaft-boring roadheaders-five pcs (Figure 11e);

6. Commercial picks for shaft-boring roadheaders-five pcs (Figure 11f);

7. Commercial picks for longwall shearers-five pcs (Figure 11g);

8. Commercial picks for longwall shearers-five pcs (Figure 11h).

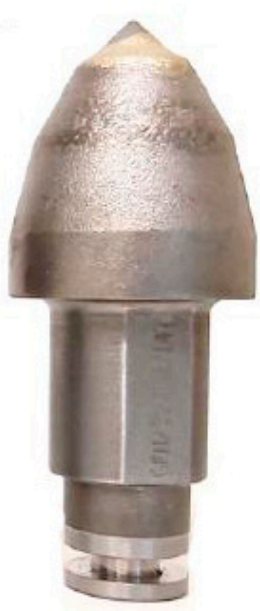

(a)

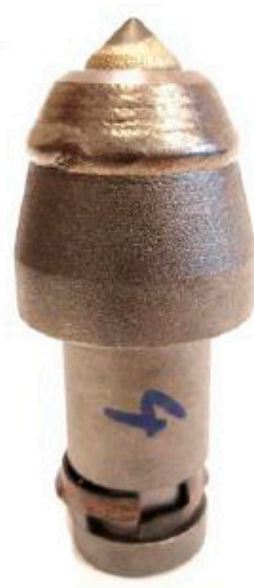

(b)

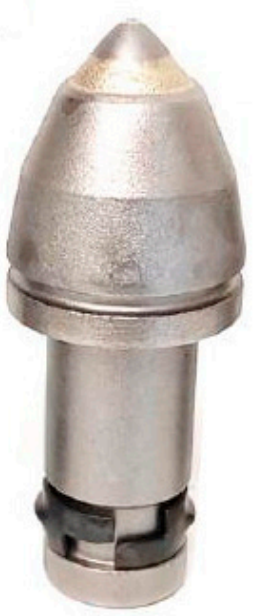

(c)

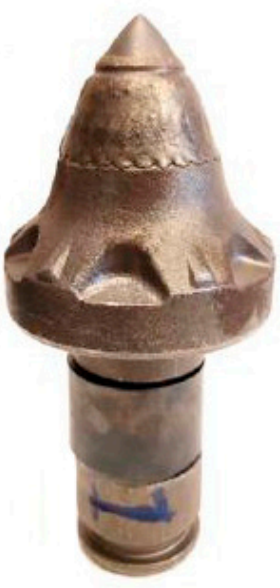

(d)

Figure 11. Cont. 


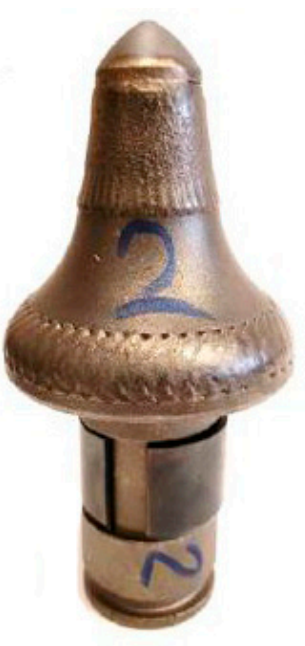

(e)

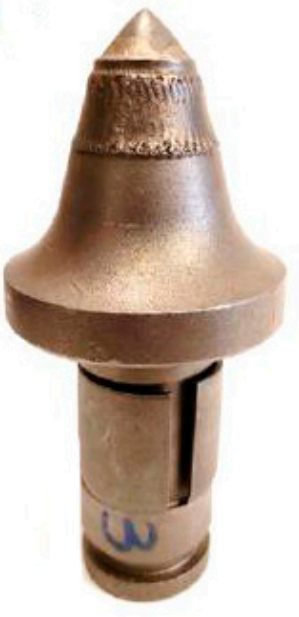

$(\mathbf{f})$

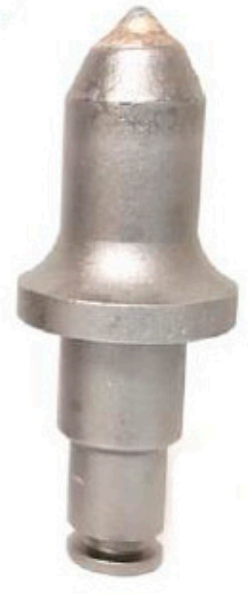

(g)

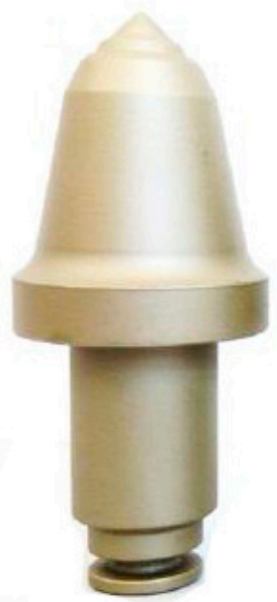

(h)

Figure 11. Types of conical picks for tests: $(\mathbf{a}-\mathbf{c})$ picks for roadheaders; $(\mathbf{d}-\mathbf{f})$ picks for shaft-boring roadheaders; (g,h) picks for longwall shearers.

\section{Conical Pick Testing Results and Discussion}

The selected conical picks were tested in accordance with the previously described procedure. The obtained results allowed for evaluating the picks and formulating conclusions regarding their design and material parameters as well as the wear rates.

\subsection{Determination of Design Parameters}

The parameters obtained from the measurements of construction dimensions' average values are summarised for each pick in Table 1 . The designations of individual parameters in the table are consistent with the designations in Figure 6. Measurement of the dimensions of the tips in the form of sintered carbide (WC-Co) inserts was possible only for one of the five picks, which was intended for material testing. For this purpose, the insert was extruded from the pick body (Figure 12). At the same time, the body of the same pick was subjected to material tests.

The results of measurements of conical picks' construction dimensions indicate that the obtained cutting angles are correct. Therefore, the rate of the picks' wear can be tested at a laboratory test stand. However, notably, the tips of two picks for shaft-boring roadheaders had a different shape (Figure 12d,f). In both cases, they were mushroom-shaped, unlike the others, which were cylindrical-conical.

Table 1. Summary of linear and angular dimensions of the tested picks.

\begin{tabular}{|c|c|c|c|c|c|c|c|c|c|c|c|}
\hline \multirow[b]{2}{*}{ No. } & \multirow[b]{2}{*}{ Pick } & \multicolumn{10}{|c|}{ Geometrical Parameters } \\
\hline & & $\begin{array}{c}\mathrm{L}_{\mathrm{c}} \\
(\mathrm{mm})\end{array}$ & $\begin{array}{c}\mathrm{L}_{\mathrm{n}} \\
(\mathrm{mm})\end{array}$ & $\begin{array}{c}\mathrm{L}_{\mathbf{u}} \\
(\mathrm{mm})\end{array}$ & $\begin{array}{c}\mathrm{h}_{\mathrm{k}} \\
(\mathrm{mm})\end{array}$ & $2 \beta_{u}\left(^{\circ}\right)$ & $\begin{array}{c}\mathrm{d}_{\mathrm{k}} \\
(\mathrm{mm})\end{array}$ & $\begin{array}{c}\mathrm{d}_{\mathrm{u}} \\
(\mathrm{mm})\end{array}$ & $\begin{array}{c}\mathrm{d}_{\mathrm{u} 1} \\
(\mathrm{~mm})\end{array}$ & $\begin{array}{c}\mathrm{d}_{\mathrm{w}} \\
(\mathrm{mm})\end{array}$ & $\begin{array}{c}\mathrm{h}_{\mathrm{w}} \\
(\mathrm{mm})\end{array}$ \\
\hline 1 & Figure 11a & 146.30 & 70.80 & 75.50 & 16.77 & 93.00 & 58.10 & 37.88 & - & 22.00 & 34.89 \\
\hline 2 & Figure $11 \mathrm{~b}$ & 146.37 & 70.82 & 75.55 & 16.82 & 93.00 & 58.17 & 37.98 & - & 22.04 & 34.87 \\
\hline 3 & Figure $11 \mathrm{c}$ & 147.20 & 71.00 & 76.20 & 15.15 & - & 57.70 & 37.98 & - & 25.28 & 35.46 \\
\hline 4 & Figure $11 d$ & 155.13 & 77.53 & 77.60 & 15.13 & 94.45 & 80.08 & 41.99 & - & $\begin{array}{c}22.11 / \\
17.85\end{array}$ & 29.11 \\
\hline 5 & Figure $11 \mathrm{e}$ & 167.64 & 90.67 & 76.97 & - & - & 80.00 & 41.88 & - & 22.04 & 33.84 \\
\hline 6 & Figure $11 \mathrm{f}$ & 156.63 & 76.69 & 79.94 & 14.10 & 93.30 & 80.00 & 41.82 & - & $\begin{array}{c}22.04 / \\
15.06\end{array}$ & 29.92 \\
\hline 7 & Figure $11 \mathrm{~g}$ & 165.22 & 90.25 & 74.97 & 12.22 & 92.97 & 58.00 & 37.80 & 29.89 & 22.05 & 35.20 \\
\hline 8 & Figure $11 \mathrm{~h}$ & 165.44 & 90.30 & 75.14 & 16.32 & 93.00 & 64.88 & 37.89 & - & 22.12 & 34.86 \\
\hline
\end{tabular}




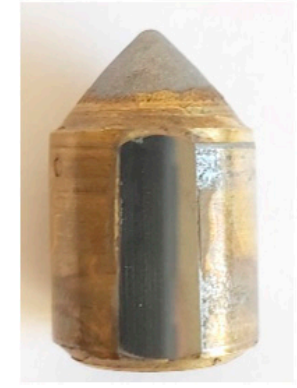

(a)

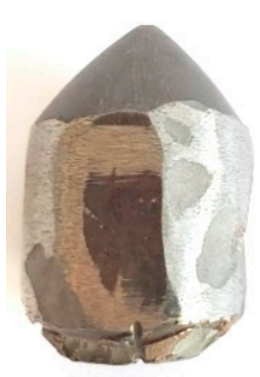

(e)

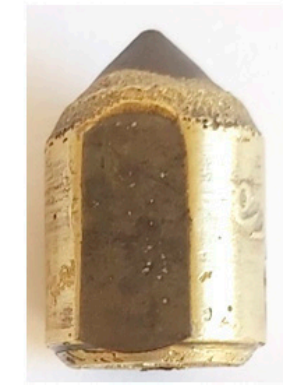

(b)

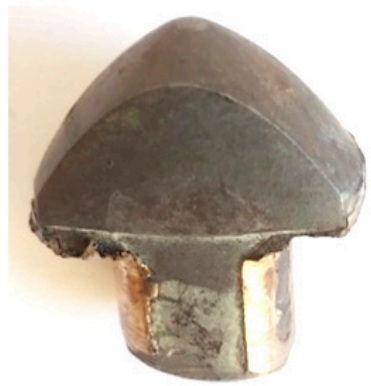

(f)

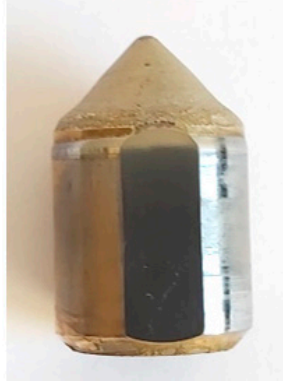

(c)

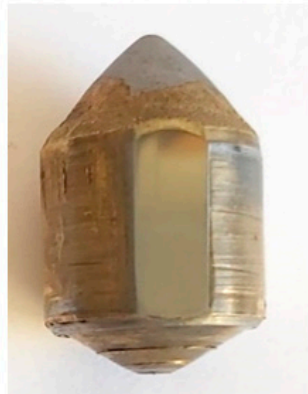

(g)

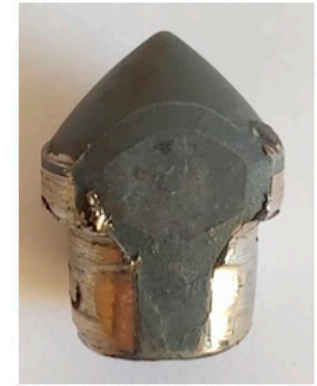

(d)

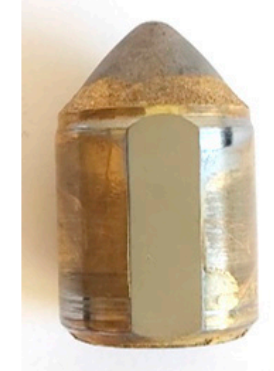

(h)

Figure 12. Tips in the form of WC-Co inserts, obtained by extruding from the tested picks: (a) pick for roadheaders (Figure 11a); (b) hardfaced pick for roadheaders (Figure 11b); (c) pick for roadheaders (Figure 11c); (d) pick for shaftboring roadheaders (Figure 11d); (e) pick for shaft-boring roadheaders (Figure 11e); (f) pick for shaft-boring roadheaders (Figure 11f); (g) pick for longwall shearers (Figure 11g); (h) pick for longwall shearers (Figure 11h).

\subsection{Determination of Material Parameters}

As mentioned before, one pick from each batch of picks was intended for material testing. For this purpose, samples from the steel body of each pick were obtained in the process of machining (Figure 13a,b), and tips in the form of sintered carbide inserts (Figure 13c) were obtained.
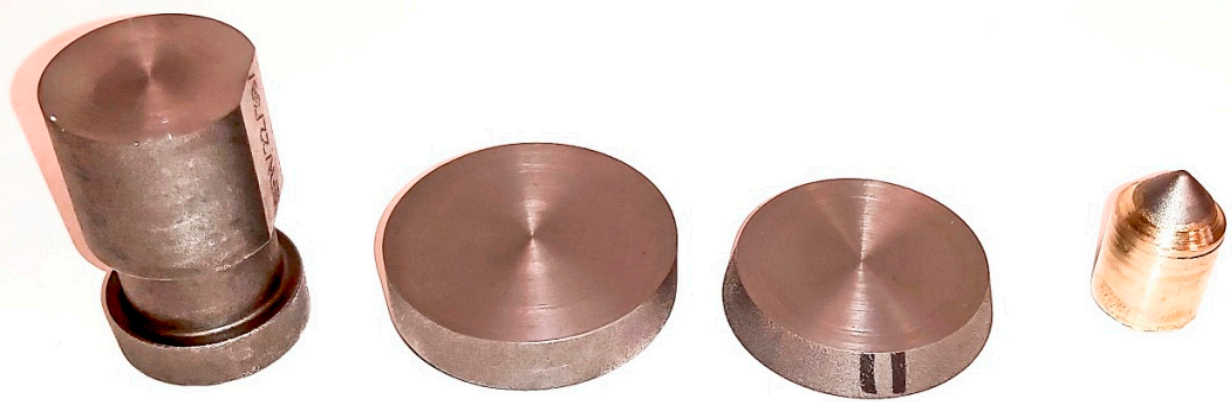

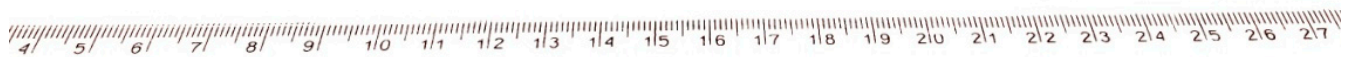

(a) (b) (c)

Figure 13. Examples of samples from a conical pick for material testing: (a) gripping part; (b) working part; (c) WC-Co insert.

The results of measurements of the tested picks' material parameters have been provided in tables, i.e., Tables 2-6, where the results of measurements for the pick used in 
roadheaders are presented (Figure 11a). The tables contain information on the hardness of the working and gripping parts, the chemical composition of the steel comprising the tested pick's body, as well as the hardness of the WC-Co insert and the value of its density. Based on this, the grade of steel used to make the bodies of the tested picks [42] and the types of carbides used to make their tips were determined. The type (symbol) of sintered carbide was determined using the PN-88/H-89500 polish standard [43], classifying sintered carbides based on WC and Co percentages, density, HV30 hardness and other mechanical parameters, and also indicates the place of their application. In the case of picks reinforced with padding weld, their hardness was additionally measured (Figure 14). The results of material tests for individual picks are given in Table 7.

Table 2. Results of measurements of HRC hardness of the gripping part of the pick for roadheaders (Figure 11a).

\begin{tabular}{|c|c|c|c|c|c|c|c|c|c|c|c|}
\hline \multirow{2}{*}{ No. } & \multicolumn{10}{|c|}{ Measurement Site Number } & \multirow{2}{*}{ Average } \\
\hline & 1 & 2 & 3 & 4 & 5 & 6 & 7 & 8 & 9 & 10 & \\
\hline 1 & 40 & 40 & 41 & 41 & 42 & 42 & 41 & 41 & 40 & 40 & 41 \\
\hline
\end{tabular}

Table 3. Results of measurements of HRC hardness of the working part of the pick for roadheaders (Figure 11a).

\begin{tabular}{cccccc}
\hline \multirow{2}{*}{ No. } & Distance from the Surface, $\mathbf{m m}$ & \multicolumn{3}{c}{ Measurement Site Number } \\
\cline { 3 - 5 } & 1 & $\mathbf{1}$ & $\mathbf{2}$ & $\mathbf{3}$ & $\mathbf{4}$ \\
\hline 1 & 3 & 35 & 35 & 35 & 35 \\
2 & 10 & 36 & 34 & 35 & 36 \\
\hline
\end{tabular}

Table 4. Chemical composition of the material (steel) of the conical pick for roadheaders (Figure 11a).

\begin{tabular}{|c|c|c|c|c|c|c|c|c|c|}
\hline \multicolumn{9}{|c|}{ Chemical Element, wt.\% } & \multirow{3}{*}{$\begin{array}{l}\text { Steel } \\
\text { Grade }\end{array}$} \\
\hline$C$ & Mn & $\mathrm{Si}$ & $S$ & $\mathbf{P}$ & $\mathrm{Cr}$ & $\mathrm{Ni}$ & Mo & $\mathbf{V}$ & \\
\hline $0.336 \downarrow$ & $0.860 \downarrow$ & $1.19 \uparrow$ & 0.0092 & 0.0154 & $1.14 \downarrow$ & 0.0766 & 0.0262 & 0.002 & \\
\hline Al & $\mathrm{Cu}$ & $\mathrm{Ti}$ & $\mathbf{W}$ & $\mathbf{P b}$ & As & Co & $\mathrm{Fe}$ & - & \multirow{2}{*}{ 100CrMn6 } \\
\hline 0.0196 & 0.173 & 0.002 & 0.015 & 0.025 & 0.01 & 0.0092 & 96.1 & - & \\
\hline
\end{tabular}

The chemical elements, the content of which is underestimated or overestimated in relation to the standard, are marked in red.

Table 5. Results of measurements of HV30 hardness of the sintered carbide insert of the pick for roadheaders (Figure 12a).

\begin{tabular}{|c|c|c|c|c|c|c|c|c|c|c|c|}
\hline \multirow{2}{*}{ No. } & \multicolumn{10}{|c|}{ Measurement Site Number } & \multirow{2}{*}{ Average } \\
\hline & 1 & 2 & 3 & 4 & 5 & 6 & 7 & 8 & 9 & 10 & \\
\hline 1 & 1076 & 1034 & 1041 & 1075 & 1111 & 1071 & 1057 & 1081 & 1125 & 1135 & 1081 \\
\hline
\end{tabular}

Table 6. Results of measurements of the density of the sintered carbide insert of the pick for roadheaders (Figure 12a).

\begin{tabular}{cccccc}
\hline No. & $\begin{array}{c}\text { Temperature of Water } \\
\text { Used for Weighing, }{ }^{\circ} \mathbf{C}\end{array}$ & $\begin{array}{c}\text { Water Density, } \\
\mathbf{g} / \mathbf{c m}^{\mathbf{3}}\end{array}$ & $\begin{array}{c}\text { Carbide Mass in } \\
\text { Air, } \mathbf{g}\end{array}$ & $\begin{array}{c}\text { Carbide Mass in } \\
\text { Water, } \mathbf{g}\end{array}$ & $\begin{array}{c}\text { Insert Density, } \\
\mathbf{g} / \mathbf{c m}^{\mathbf{3}}\end{array}$ \\
\hline 1 & 21 & 0.9975 & 149.1258 & 138.9177 & 14.572 \\
\hline
\end{tabular}




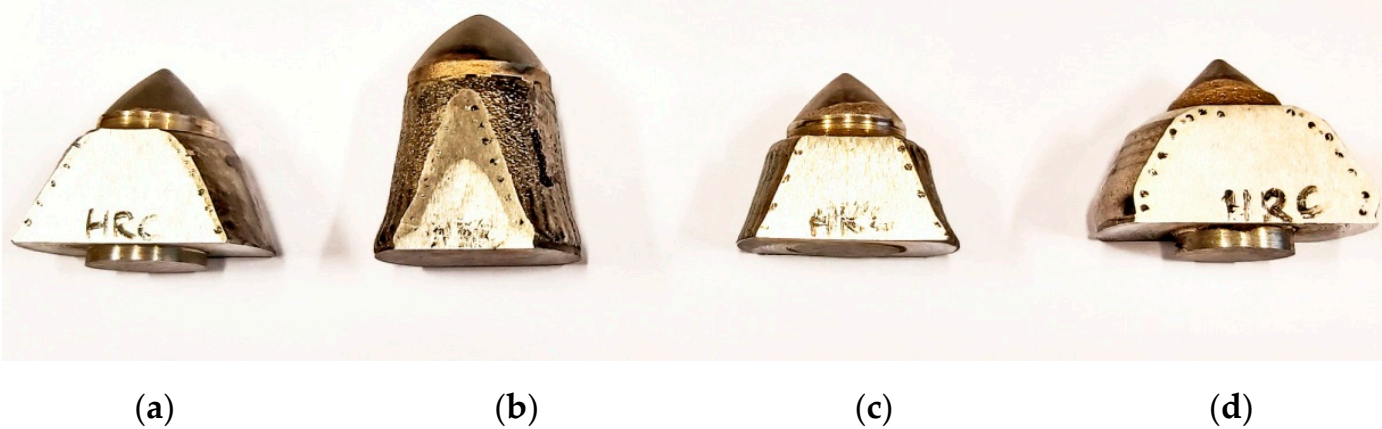

Figure 14. Examples of samples prepared for padding weld hardness tests from tested picks: (a) pick for shaft-boring roadheaders (Figure 11d); (b) pick for shaft-boring roadheaders (Figure 11e); (c) pick for shaft-boring roadheaders (Figure 11f); (d) hardfaced pick for roadheaders (Figure 11b).

Table 7. Summary of the results of material tests for individual picks.

\begin{tabular}{|c|c|c|c|c|c|c|c|c|}
\hline \multicolumn{9}{|c|}{ List of Picks } \\
\hline No. & Pick & $\begin{array}{c}\text { HRC of the } \\
\text { Gripping } \\
\text { Part }\end{array}$ & $\begin{array}{c}\text { HRC of the } \\
\text { Working } \\
\text { Part }\end{array}$ & $\begin{array}{l}\text { Steel } \\
\text { Grade }\end{array}$ & $\begin{array}{c}\text { HV30 of the } \\
\text { Carbide }\end{array}$ & $\begin{array}{l}\text { Carbide } \\
\text { Density }\end{array}$ & $\begin{array}{l}\text { Type of } \\
\text { Carbide }\end{array}$ & $\begin{array}{l}\text { HRC of the } \\
\text { Padding } \\
\text { Weld }\end{array}$ \\
\hline 1 & Figure 11a & 41 & 35 & 100CrMn6 & 1081 & 14,572 & B45 & - \\
\hline 2 & Figure $11 \mathrm{~b}$ & 45 & 35 & 100CrMn6 & 1127 & 14,408 & B45 & 62 \\
\hline 3 & Figure $11 \mathrm{c}$ & 40 & 43 & $100 \mathrm{CrMn} 6$ & 1143 & 14,378 & B40 & - \\
\hline 4 & Figure $11 \mathrm{~d}$ & 46 & 46 & 36Mn5 & 1326 & 13,959 & G15 & 56 \\
\hline 5 & Figure $11 \mathrm{e}$ & 44 & 47 & 36Mn5 & 1168 & 14,629 & B23 & $\begin{array}{c}65^{*} \\
59^{* *}\end{array}$ \\
\hline 6 & Figure 11f & 47 & 43 & 100CrMn6 & 1158 & 14,197 & G30 & 51 \\
\hline 7 & Figure $11 \mathrm{~g}$ & 38 & 38 & 100CrMn6 & 1155 & 14,821 & B23 & - \\
\hline 8 & Figure $11 \mathrm{~h}$ & 41 & 44 & 100CrMn6 & 1124 & 14,483 & B40 & - \\
\hline
\end{tabular}

${ }^{*}$ Padding weld on the carbide. ${ }^{* *}$ Padding weld on the working part flange.

The test results contained therein show that, with the exception of picks 5 and 6 whose bodies were made of manganese alloy steel (36Mn6), the remaining picks were made of chrome-manganese (100CrMn6) steel. The hardness of the working part of the picks was mostly above $40 \mathrm{HRC}$; its value was lower- 38 HRC only in the case of pick No. 8. A similar situation was observed in the case of the tested picks' gripping parts. The hardness values of the gripping parts of picks 1 and $2(35 \mathrm{HRC})$ were lower than that of the working parts (over $40 \mathrm{HRC}$ ), which is an advantage because the pick-holder sockets are not knocked out. On the other hand, the values of padding welds hardness were much higher, exceeding 60 HRC.

Measurements of the hardness and density of the WC-Co inserts allowed for determining their grade. B23 cemented carbide inserts are recommended for cross-bits and drills (picks 6,8). The properties of these carbides were intermediate, between those of B2 and B45 carbides. B40 carbides are intended for reinforcing the tips of radial tools and rotary drilling tools (drill bits, multi-step bits, picks 3 and 8), whereas B45 carbides are used to reinforce the tips of conical picks, cross-bits and drills (picks 1, 2). G15 (pick 5) and G30 (pick 7) carbides are recommended for insert bits and discs $[17,19,34,44]$.

For WC-Co cemented carbide inserts, quantitative analysis of the WC carbide phase was also performed. For this purpose, the test specimens were prepared by the traditional method of grinding and polishing metallographic specimens using polish suspensions with a diamond grain, with coarseness values of $3 \mu \mathrm{m}, 1 \mu \mathrm{m}$ and $0.25 \mu \mathrm{m}$. The prepared specimens were subjected to chemical etching in order to reveal the boundaries of WC carbide grains (Figure 15) [45]. 


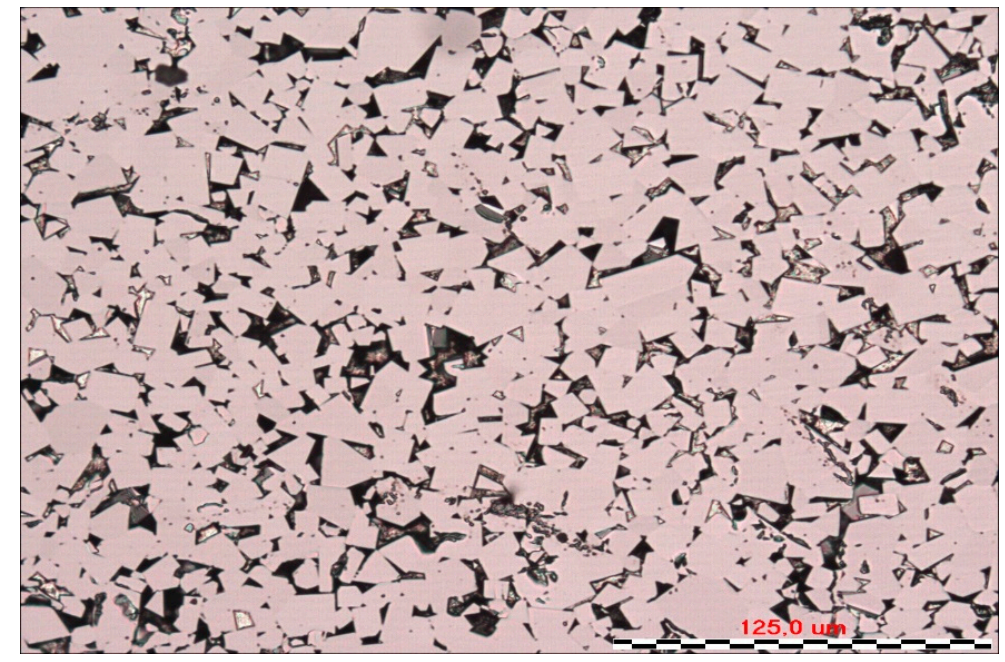

Figure 15. Microstructure of the tip made of sintered tungsten carbide-cobalt (WC-Co) of the conical pick for roadheaders (Figure 11a).

WC grains were measured for all tested WC-Co inserts. The average WC particle size ranged from $4.78 \mu \mathrm{m}$ to $6.15 \mu \mathrm{m}$, and the cobalt content from $8.4 \%$ to $9.5 \%$.

Analytical and empirical studies have shown that the best properties of WC-Co inserts for mining tools are $9 \%$ cobalt content (hardness, impact toughness). The size of the WC grains is also important. Based on the literature [24] and our previous work, the average grain size should be above $3 \mu \mathrm{m}$.

\subsection{Determination of the Rate (Intensity) of Wear}

To determine the rate (intensity) of wear of the tested picks, first, the values of their mass before and after the test were determined. Next, the cutting parameters (advance speed, revolutions) were set, and efforts were made to ensure the same conditions for each set of picks. On the same sand-cement sample with uniaxial compressive strength equal to $35 \mathrm{MPa}$, all picks were tested. The results of the tests and the determined values of the $C 2$ index for individual picks are summarised in Table 8. Based on these results, a table of $C 2$ index values was prepared depending on the pick's location in the test drum (Figure 10, Table 8). Similarly, Figure 16 shows the $C 2$ index point values for individual picks as a function of the test drum's location.

Table 8. Summary of $C 2$ index values for the tested picks depending on the location on the test drum.

\begin{tabular}{cccccc}
\hline \multirow{2}{*}{ No. } & \multirow{2}{*}{ Pick } & \multicolumn{4}{c}{ Location of the Pick on the Test Drum } \\
\cline { 3 - 5 } & & $\mathbf{4}$ & $\mathbf{1}$ & $\mathbf{2}$ & $\mathbf{3}$ \\
\hline 1 & Figure 11a & 41.958 & 112.020 & 78.657 & 9.486 \\
2 & Figure 11b & 32.150 & 84.470 & 72.652 & 12.317 \\
3 & Figure 11c & 3.148 & 22.155 & 17.946 & 0.965 \\
4 & Figure 11d & 55.756 & 89.902 & 103.275 & 13.029 \\
5 & Figure 11e & 0.055 & 0.254 & 0.038 & 33.744 \\
6 & Figure 11f & 2.241 & 18.187 & 42.907 & 3.832 \\
7 & Figure 11g & 29.350 & 74.907 & 38.679 & 3.831 \\
8 & Figure 11h & 17.050 & 56.395 & 53.592 & 1.082 \\
\hline & Average value & 18.515 & 46.881 & 41623 & 8.165 \\
\hline
\end{tabular}




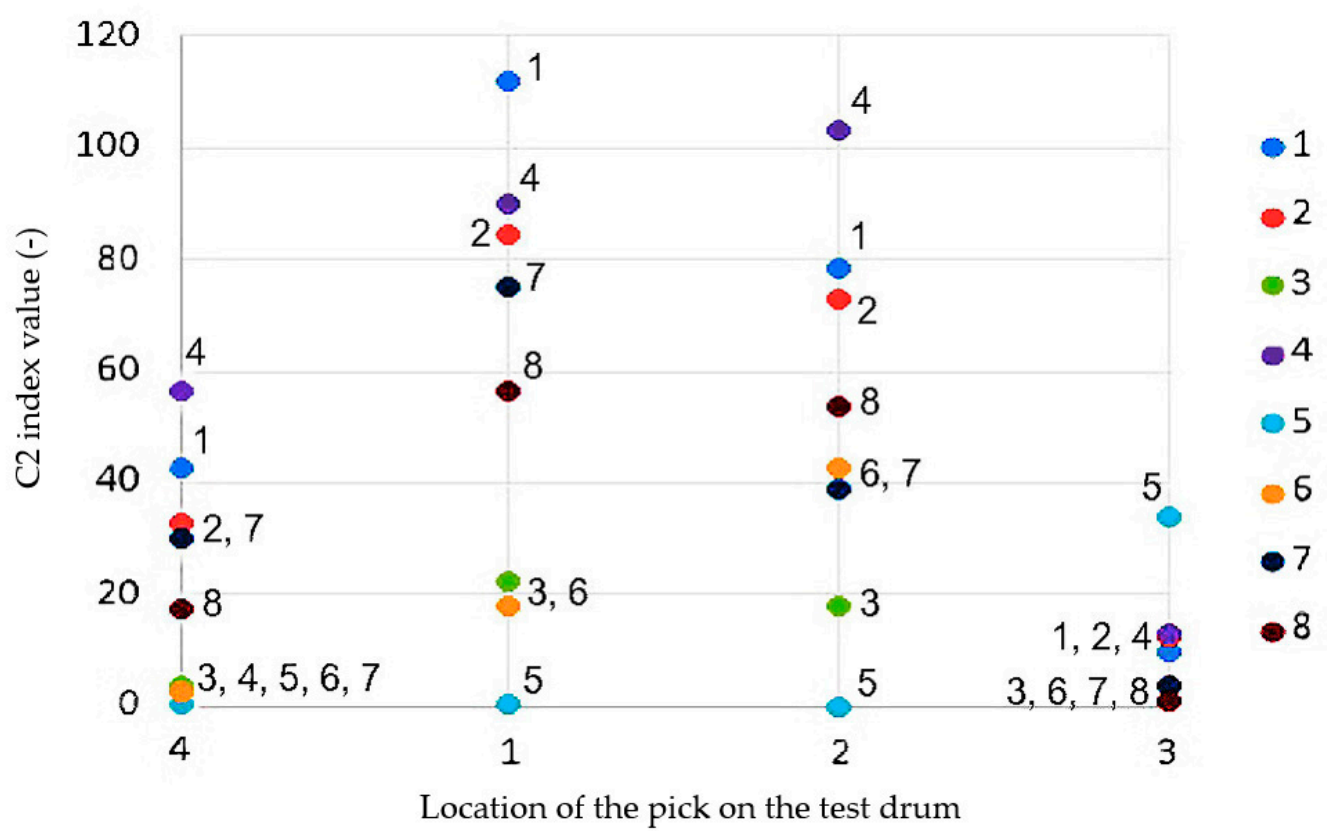

Figure 16. $C 2$ index values for individual picks and their locations on the test drum.

The above comparisons clearly show a strong correlation between the pick's wear rate and their position on the test drum. The wear rate was the fastest for picks in position one and two, followed by picks in position four, whereas picks in position three wore the most slowly. It can also be observed that a specific pick wears differently depending on the position on the test drum, as already mentioned, although this wear expressed by $C 2$ index correlated with its quality.

The average values for individual picks are summarised in Table $9(C 2$, the presence of padding weld, type of cemented carbide insert, and the hardness of the working part).

Table 9. Summary of the results of average values for individual picks.

\begin{tabular}{|c|c|c|c|c|c|}
\hline \multicolumn{6}{|c|}{ List of Picks } \\
\hline No. & Pick & C2 Index & Padding Weld & $\begin{array}{l}\text { Type of } \\
\text { Carbide }\end{array}$ & $\begin{array}{l}\text { HRC of the } \\
\text { Working Part }\end{array}$ \\
\hline 5 & $\begin{array}{l}\text { Pick for shaft-boring roadheaders } \\
\text { (Figure 11e) }\end{array}$ & 8.513 & padding weld & B23 & 44 \\
\hline 3 & Pick for roadheaders (Figure 11c) & 11.054 & missing & $\mathrm{B} 40$ & 40 \\
\hline 6 & $\begin{array}{l}\text { Pick for shaft-boring roadheaders } \\
\text { (Figure 11f) }\end{array}$ & 16.792 & padding weld & G30 & 47 \\
\hline 8 & Pick for longwall shearers (Figure 11h) & 32.030 & missing & B40 & 41 \\
\hline 7 & Pick for longwall shearers (Figure 11g) & 36.692 & missing & B23 & 38 \\
\hline 2 & Pick for roadheaders (Figure 11b) & 50.397 & padding weld & B45 & 41 \\
\hline 1 & Pick for roadheaders (Figure 11a) & 60.530 & missing & B45 & 45 \\
\hline 4 & $\begin{array}{l}\text { Pick for shaft-boring roadheaders } \\
\text { (Figure 11d) }\end{array}$ & 65.490 & padding weld & G15 & 46 \\
\hline
\end{tabular}

It can be observed that the tested picks considerably differed in their wear rate, which is puzzling and does not depend or depends only to a minimal extent on the protective layer of the working part (padding weld). The lowest wear (C2 index) was observed in the case of the pick in position 1 (Table 9). The next pick in the table had a 30\% higher $C 2$ index value. In contrast, the $C 2$ index value of the third pick was twice as high. The $C 2$ index values for the fourth and fifth pick were almost four times higher. The $C 2$ index value for the sixth pick was six times higher, and for the seventh and eighth pick, this rose 
to eight times higher. It is also worth noting that the padding weld and carbide grade do not determine the wear rate of the pick, as with the hardness of the working part.

Generally, it is possible to use the $C 2$ index to assess the pick's wear resistance. The lower the $C 2$ index value, the longer the pick should cut while meeting the cutting process requirements. As a result, it is possible to forecast the value of picks' wear and, consequently, their purchase cost. In this case, it is easy to determine the maximum price of a pick with a lower $C 2$ index value by referring it to the price of picks with a higher $C 2$ index value. It is enough to multiply the prices of the picks by the ratio of their $C 2$ index values.

\section{Conclusions}

In the presented method of assessing the quality of conical picks, a three-stage testing process was adopted, consisting of measuring geometric and material parameters and the wear rate, expressed by the $C 2$ index. The tests carried out on eight types of conical picks from different manufacturers have shown that their geometric and material parameters are in accordance with the manufacturers' declarations and users' requirements. However, based on these data, it is only possible to assess the correctness of their manufacture, not their quality. Only when a complete procedure is carried out can the quality of the pick be assessed.

This strategy was confirmed by comparing two picks for shaft-boring roadheaders (Figures $11 \mathrm{~d}$ and $12 \mathrm{e}$ ). Both picks were made of the same $36 \mathrm{Mn} 5$ steel, their working part hardness was the same, and both were welded, although the pick for the shaft-boring roadheader in Figure $11 \mathrm{~d}$ had a $C 2$ index value as much as eight times greater than the pick for shaft-boring roadheaders in Figure 11e, which means that its quality is eight times lower.

It follows that particular attention should be paid to the $C 2$ index because, as a result of this research, it does illustrate the wear rate of the pick and thus its durability (quality). However, carrying out a complete procedure also allows conclusions in the future and indicates further research directions to improve the quality of conical picks. For example, it was noticed that further attention should be paid to the correlations between the hardness of the working part and padding weld and the value of the $C 2$ index.

Determining the $C 2$ index, it can also be observed that the position of the pick on the test drum and, presumably, the sequence of entering the cut have a significant influence on the pick wear process. Moreover, the $C 2$ index enables defining various causes related to the value and the price of the picks, as well as the costs of their replacement and reduced cutting efficiency. In most cases, it has been established that picks of better quality (the lowest value of the $C 2$ index) should be used regardless of the price. However, there are cases where a pick's choice depends on its price and losses in cutting.

The $C 2$ index is the parameter that best describes the quality of the pick; therefore, it is recommended that the proposed method and procedure should be used to evaluate picks both when placing orders and to file complaints, but also in other cases, whenever cutting tools need to be selected.

Author Contributions: Conceptualization, K.K.; methodology, K.K.; software, T.W.; validation, K.K. and K.M.; formal analysis, K.K. and K.M.; investigation, K.K., K.M. and T.W.; resources, K.K.; data curation, K.M.; writing — original draft preparation, K.K. and K.M.; writing-review and editing, K.M.; visualization, K.M. and T.W.; supervision, K.K. and E.P.; project administration, K.M.; funding acquisition, K.K. All authors have read and agreed to the published version of the manuscript.

Funding: The research was funding by AGH University of Science and Technology, Kraków, Poland.

Data Availability Statement: Data presented in the article are original and not inappropriately selected, manipulated, enhanced, or fabricated.

Conflicts of Interest: The authors declare no conflict of interest. 


\section{References}

1. Bilgin, N.; Copur, H.; Balci, C. Mechanical Excavation in Mining and Civil Industries; CRC Press: Boca Raton, FL, USA, 2013.

2. Jonak, J. Urabianie Skał Głowicami Wielonarzędziowymi; Śląsk Press: Katowice, Poland, 2002. (In Polish)

3. Krauze, K. Urabianie Skat Kombajnami Ścianowymi: Podstawy Doboru i Projektowania Elementów Frezujących; Śląsk Press: Katowice, Poland, 2000. (In Polish)

4. Beer, G. Technology Innovation in Underground Construction; CRC Press: Boca Raton, FL, USA, 2009.

5. Cheluszka, P. Optimization of the Cutting Process Parameters to Ensure High Efficiency of Drilling Tunnels and Use the Technical Potential of the Boom-Type Roadheader. Energies 2020, 13, 6597. [CrossRef]

6. Kotwica, K. Atypical and innovative tool, holder and mining head designed for roadheaders used to tunnel and gallery drilling in hard rock. Tunn. Undergr. Space Technol. 2018, 82, 493-503. [CrossRef]

7. Kotwica, K.; Krauze, K. Selection and underground tests of the rotary tangential cutting picks used in cutting heads of the longwall and roadway miners. Arch. Min. Sci. 2007, 52, 195-217.

8. Kotwica, K.; Małkowski, P. Methods of Mechanical Mining of Compact-Rock-A Comparison of Efficiency and Energy Consumption. Energies 2019, 12, 3562. [CrossRef]

9. Krauze, K. Urabianie Skat Strugami Statycznymi: Podstawy Doboru i Projektowania Kompleksów Strugowych; Śląsk Press: Katowice, Poland, 2012. (In Polish)

10. Peng, S.S. Longwall Mining; CRC Press: Boca Raton, FL, USA, 2019.

11. Tatiya, R.R. Surface and Underground Excavations-Methods, Techniques and Equipment; CRC Press: Boca Raton, FL, USA, 2018.

12. Yang, D.; Jianping, L.; Zheng, K.; Jiang, H.; Handong, X.; Liu, S. High-hardness alloy substituted by low hardness during drilling and cutting experiments of conical pick. Int. J. Rock Mech. Min. Sci. 2017, 95, 73-78. [CrossRef]

13. Longwall Systems. Available online: https://mining.komatsu/underground-mining/longwall-systems (accessed on 10 January 2021).

14. Roadheaders. Available online: https:/ / famur.com (accessed on 10 January 2021).

15. Shaft Boring Roadheader. Available online: https://www.herrenknecht.com/en/products/productdetail/shaft-boringroadheader-sbr (accessed on 10 January 2021).

16. Kotwica, K. Effect of selected working conditions of cutting picks on their wear during the mining of hard rocks. Q. Mech. Control 2010, 29, 110-119.

17. Liu, S.; Ji, H.; Liu, X.; Jiang, H. Experimental research on wear of conical pick interacting with coal-rock. Eng. Fail. Anal. 2017, 74, 172-187. [CrossRef]

18. Wang, S.; Li, X.; Yao, J.; Gong, F.; Li, X.; Du, K.; Tao, M.; Huang, L.; Du, S. Experimental investigation of rock breakage by a conical pick and its application to non-explosive mechanized mining in deep hard rock. Int. J. Rock Mech. Min. Sci. 2019, $122,104063$. [CrossRef]

19. Wang, X.; Su, O. Specific energy analysis of rock cutting based on fracture mechanics: A case study using a conical pick on sandstone. Eng. Fract. Mech. 2019, 213, 197-205. [CrossRef]

20. Cold Milling Machines. Available online: https://www.wirtgen-group.com (accessed on 10 January 2021).

21. Bołoz, Ł. Results of a study on the quality of conical picks for public procurement purposes. New Trends Prod. Eng. 2018, 1, 687-693. [CrossRef]

22. Bołoz, Ł. Directions for increasing conical picks' durability. New Trends Prod. Eng. 2019, 2, 277-286. [CrossRef]

23. Bołoz, Ł.; Kalukieiwcz, A.; Galecki, G.; Romanyshyn, L.; Romanyshyn, T.; Giménez, R.B. Conical Pick Production Process. New Trends Prod. Eng. 2020, 3, 231-240. [CrossRef]

24. Ścieszka, S.; Filipowicz, K. Materiały na Narzędzia Górnicze; Wydawnictwo Politechniki Śląskiej: Gliwice, Poland, 2001. (In Polish)

25. Garbiec, D.; Siwak, P. Microstructural evolution and development of mechanical properties of spark plasma sintered WC-Co cemented carbides for machine parts and engineering tools. Arch. Civ. Mech. Eng. 2019, 19, 215-223. [CrossRef]

26. Nahak, S.; Dewangan, S.; Chattopadhyaya, S.; Krolczyk, G.; Hloch, S. Discussion on importance of tungsten carbide-Cobalt (WC-Co) cemented carbide and its critical characterization for wear mechanisms based on mining applications. Arch. Min. Sci. 2018, 63, 229-246.

27. Dewangan, S.; Chattopadhyaya, S. Performance Analysis of Two Different Conical Picks Used in Linear Cutting Operation of Coal. Arab. J. Sci. Eng. 2016, 41, 249-256. [CrossRef]

28. Krauze, K.; Bołoz, Ł.; Wydro, T. Parametric factors for the tangential-rotary picks quality assessment. Arch. Min. Sci. 2015, 60, 265-281.

29. Krauze, K.; Mucha, K.; Wydro, T. Evaluation of the Quality of Conical Picks and the Possibility of Predicting the Costs of Their Use. Multidiscip. Asp. Prod. Eng. MAPE 2020, 3, 491-504.

30. Li, H.S.; Liu, S.Y.; Xu, P.P. Numerical simulation on interaction stress analysis of rock with conical picks. Tunn. Undergr. Space Technol. 2019, 85, 231-242. [CrossRef]

31. Li, W.; Wang, S.; Ge, S.; Malekian, R.; Li, Z. A Theoretical Model for Estimating the Peak Cutting Force of Conical Picks. Exp. Mech. 2018, 58, 709-720. [CrossRef]

32. Yasar, S. A General Semi-Theoretical Model for Conical Picks. Rock Mech. Rock Eng. 2020, 53, 2557-2579. [CrossRef]

33. Mucha, K. The new method for assessing rock abrasivity in terms of wear of conical picks. New Trends Prod. Eng. 2019, 2, 186-194. [CrossRef] 
34. Sikora, W. (Ed.) Determination of Forces and Energy Consumption of Excavation with Conical Picks; The Silesian University of Technology Press: Gliwice, Poland, 2000.

35. Yasar, S. Predictive plots for conical pick performance using mechanical and elastoplastic properties of rocks. J. Rock Mech. Geotech. Eng. 2020, 12, 1027-1035. [CrossRef]

36. Krauze, K.; Skowronek, T.; Mucha, K. Influence of the hard-Faced layer welded on tangential—Rotary pick operational part on to its wear rate. Arch. Min. Sci. 2016, 61, 779-792. [CrossRef]

37. Krauze, K.; Bołoz, Ł.; Wydro, T.; Mucha, K. Durability testing of tangential—Rotary picks made of different materials. Min. Inform. Autom. Electr. Eng. 2017, 1, 26-34. [CrossRef]

38. ISO 6508-1: Metallic Materials—Rockwell Hardness Test. Part 1: Test Method; Organization for Standardization: Geneva, Switzerland, 2016; Available online: https: / / www.iso.org/standard/70460.html (accessed on 12 March 2021).

39. ISO 3369: Impermeable Sintered Metal Materials and Hardmetals—Determination of Density; Organization for Standardization: Geneva, Switzerland, 2006; Available online: https:/ / www.iso.org/standard/44435.html (accessed on 12 March 2021).

40. PN EN 23878. Węgliki Spiekane_Pomiar Twardości Sposobem Vickersa; Polish Committee for Standardization: Warszawa, Poland, 1996. (In Polish)

41. Szala, J. Zastosowanie Metod Komputerowej Analizy Obrazu do Ilościowej Oceny Struktury Materiałów; Politechnika Ślaska: Gliwice, Poland, 2001. (In Polish)

42. ISO 683-2: Heat-Treatable Steels, Alloy Steels and Free-Cutting Steels-Part 2: Alloy Steels for Quenching and Tempering; Organization for Standardization: Geneva, Switzerland, 2016; Available online: https:/ /www.iso.org/standard/70643.html (accessed on 25 March 2021).

43. PN-88/H-89500 Węgliki Spiekane-Gatunki; Polish Committee for Standardization: Warszawa, Poland, 1988. (In Polish)

44. Brox, D. Practical Guide to Rock Tunneling; CRC Press: Boca Raton, FL, USA, 2017.

45. ISO 4499-1: Hardmetals-Metallographic Determination of Microstructure. Part 1: Photomicrographs and Description; Organization for Standardization: Geneva, Switzerland, 2006; Available online: https: / /www.iso.org/standard/43500.html (accessed on 9 February 2021). 